\title{
RESEARCH REGARDING THE EFFICIENCY OF SOYBEAN CULTIVATION IN DIFFERENT TILLAGE SYSTEMS AND THEIR INFLUENCE ON SOIL COMPACTION, ACCUMULATION AND WATER STORAGE
}

\author{
Felicia Chețan ${ }^{1 *}$, Cornel Chețan ${ }^{1}$, Felicia Mureşanu ${ }^{1}$, Loredana Suciu ${ }^{1,2}$, Ioana Crişan ${ }^{1}$ \\ ${ }^{1}$ Agricultural Research and Development Station Turda, Romania \\ ${ }^{2}$ University of Agricultural Sciences and Veterinary Medicine, Cluj-Napoca, Romania \\ *Corresponding author: \\ Agricultural Research and Development Station Turda \\ 27 Agriculturii Street, 401100, Turda, Cluj, Romania \\ Tel: $+40264311680(1)$ \\ Fax: +40264311792 \\ E-mail:felice_fely@yahoo.com \\ http://www.doi.org/10.54574/RJPP.14.01
}

\begin{abstract}
In the last years there has been a slight increase in average annual temperatures, as well as a high fluctuation in the distribution of rainfall, thus the reduction of the effects of atmospheric and pedological drought is part of the reasons that determine the orientation towards new variants of soil tillage. The experiment conceived and performed at ARDS Turda includes four variants of soil tillage: plow with the turn of the furrow (CS), chisel (MT), disk (MD) and no tillage (NT), in a 3-year crop rotation of soybean - winter wheat - maize. The momentary water reserve was higher in the MD and NT system compared to the CS, MT. The specific resistance of the soil to penetration (Rp) in NT, MD are higher compared to the CS and MT systems. Soybeans can be cultivated in a MT, the yield difference compared to the CS is $107 \mathrm{~kg} / \mathrm{ha}$. Compared to CS $(66.5 \mathrm{~L} / \mathrm{ha})$ significant reductions of diesel consumption are made in the MD system $(21 \mathrm{~L} / \mathrm{ha})$ and in the NT $(31.7 \mathrm{~L} / \mathrm{ha})$.
\end{abstract}

Key words: soybean, soil compaction, water reserve

\section{INTRODUCTION}

The particular importance of soybean comes from its multiple usages both in the alimentation of people (oil, the mature beans and the green hulls are used in various food recipes) (Subramanian \& Smith, 2013; Cvijanovic \& Cvijanovic, 1988) and in the feeding of animals as well as in industry (oils for painting, the production of plastic mass, the preparation of margarine). It is also used in the regeneration of the physical properties of the soil due to the symbiosis which is installed between the radicular system and the Bradyrhizobium japonicum bacteria (Stevanović et al., 2016; Popović et al., 2018; Cheţan, 2020).

Plowing as a basic work followed by the seedbed preparation and the maintenance works specific to the classical tillage system involve an intense traffic of machines, which in time lead to soil compaction (increases the bulk density, decreases the total porosity and hydraulic conductivity, changes the regime aero-hydric) but it is a significant consumer of energy resources (Serrano et al., 2007; Chețan \& Chețan, 2020). As a result of soil compaction, the negative effect on agricultural crop is reflected by reducing the production potential (Marchenko et al, 2009).

Alternative minimum tillage systems and no tillage involve reduced intervention on the soil, keeping plant debris at the soil surface by at least $50-60 \%$ performing the role of soilprotecting mulch. Soil is thus protected from surface erosion, soil aggregates are stabilized, organic matter and fertility levels will increase, soil compaction and decrease in $\mathrm{CO}_{2}$ emissions, increased biodiversity (Pisante \& Stagari, 2011; Marin et al., 2015; Sabo et al., 2007; Topa et 
al., 2012; Chețan, 2019). Vegetable residues left on the surface of the soil protect it and, under the action of micro-organisms and macro-organisms in the process of transformation, contribute to the improvement of soil structure (Ulrich et al., 2006; Wozniak et al., 2014).

The choice of the optimal technological variant must take into account the technological properties of the soil: texture, humidity, soil exposure, macro and microclimate, humus content, etc., but also the climatic conditions of the agricultural year and the technological capacity to capitalize on these resources (Szajdak \& Rusu, 2016; Cheţan et.al, 2019; 2020).

The registered climatic changes (increasing temperatures, decrease in rainfall or nonuniformity of rainfall), as well as the unpredictable ones in the future require the judicious choice of the biological material to be cultivated and the application of some technologies adequate to the new climatic conditions, that why the applied agrotechnical measures must be adapted to more oscillating ecological conditions

The paper presents the results of research conducted in year 2020, regarding the influence of tillage systems on the compaction, accumulation and storage of water in the soil in the case of soybean culture, under the conditions of the Agricultural Research and Development Station Turda (ARDS Turda), the economic efficiency of the tillage systems was also determined.

\section{MATERIAL AND METHODS}

The experiment has been conducted at ARDS Turda situated in physiographic section Transylvanian Plain (Transylvanian Depression physiographic province), $23^{\circ} 47^{\prime}$ longitude, $46^{\circ} 35^{\prime}$ latitude and $345-493 \mathrm{~m}$ ). Zone is characterised by average multiannual rainfall of 531.4 $\mathrm{mm}$ and multiannual temperature of $9.2^{\circ} \mathrm{C}$ (for 63 years).

The experiment was included in a crop rotation of 3 years: soybean - winter wheat maize. Teo TD soybean variety was chosen for this trial. The experiment was conducted on fertile soil (haplic chernozem), but also with susceptibility to rapid compaction when passes the large agricultural aggregates, or when working mechanically in conditions of high humidity, the soil moisture of $24-25 \%$ is high enough to produce a surface compaction. The land on which the experiment was set up has a high clay content (more than $45 \%$ ).

The experimental factors were the following: factor A - tillage system with four graduations: $a_{1}$ classic with plow (CS), a $a_{2}$ minimum tillage with chisel (MT), a3 minimum tillage with heavy disk (MD), a4 direct sowing - no-tillage (NT); factor B - fertilization with four graduation: $b_{1} \mathrm{~N}_{40} \mathrm{P} 40$ at sowing, $b_{2}$ gulle manure 5 tons/ha before sowing $+\mathrm{N}_{40} \mathrm{P}_{40}$ at sowing, $b_{3}$ green fertilizer (autumn rape) $+\mathrm{N}_{40} \mathrm{P}_{40}$ at sowing, $\mathrm{b}_{4}$ green fertilizer (autumn rape) + gulle manure 10 tons $/ \mathrm{ha}+\mathrm{N}_{40} \mathrm{P}_{40}$ at sowing.

The sowing was done with the Directa 400 machine (at the same time as sowing was applied the fertilizer $\mathrm{N}_{40} \mathrm{P}_{40} \mathrm{~K}_{0}$ active substance/ha, at $18 \mathrm{~cm}$ distance between the rows, the seed introduced at $4 \mathrm{~cm}$ depth, density 45 germinative grains $/ \mathrm{m}^{2}$.

Weeds control in all variants was carried out in two stages: pre-emergence with 0.35 liter/ha metribuzin $(600 \mathrm{~g} / \mathrm{l})+1.5$ liter/ha S-metolachlor $(960 \mathrm{~g} / \mathrm{l})$; post-emergence with 1.0 liter/ha imazamox $(40 \mathrm{~g} / \mathrm{l})+1.0$ liter/ha propaquizafop $(100 \mathrm{~g} / \mathrm{l})$, in soybean phase 3 - 4 trifoliate leaves.

At the pest signalling, a treatment with 0.8 liter/ha acaricide based on propargite $(570$ g/l) was performed to control Tetranychus urticae and a treatment based on thiacloprid (240 $\mathrm{g} / \mathrm{l})$ for Vanessa cardui in dose 0.2 liter/ha.

The soil moisture was determined monthly by the reflectometric method with the Aquaterr MT-300 device, which measures the dielectric constant of the soil (variation of soil 
permittivity). The soil is a dielectric that has a low permittivity in the dry state $(\varepsilon=4-6)$ while the dielectric constant of water is high $(\varepsilon=80.08)$.

Harvesting in experimental plots of $28 \mathrm{~m}^{2}$ each was realised in first ten days of October with the combine. After the soybean harvesting, the yield was corrected to $13 \%$ moisture content and the soil compaction was determined at certain depth using the SC-900 penetrometer. It is important to know this indicator to establish the degree of soil compaction depending on the applied technology, on the measuring depth of $0-50 \mathrm{~cm}$.

The economic efficiency of the researched variants was determined depending on the fuel consumption (based on the characteristics of agricultural machines and used equipment, works executed on a land with a slope coefficient of $1.19 \%$ ), reported per hectare, average price for the purchase of diesel 4.1 lei/liter.

The results were statistically processed according to the variance analysis method and establishing the lowest significant differences, LSD (5\%, 1\% and 0.1\%) (ANOVA, 2015).

Morphological, physical and chemical data of soil in the experimental field are shown in Table 1 and 2 (Office for Pedological and Agrochemical Studies Cluj-Napoca, 2017).

Table 1. Soil profile morphological description

\begin{tabular}{|c|l|}
\hline $\begin{array}{c}\text { Horizons/depth } \\
(\mathrm{cm})\end{array}$ & \multicolumn{1}{c|}{ Description } \\
\hline $\mathrm{Am} / 0-28$ & $\begin{array}{l}\text { clay loam, very dark greyish brown 10YR 3/3-wet, dark brown 10YR 3/4- dry, moderately } \\
\text { moist, weakly cemented, granular structure, very fine to medium, strong (grade), friable, } \\
\text { moderately plastic, moderately hard, moderately sticky, very slightly effervescence, slightly } \\
\text { calcareous, many roots }\end{array}$ \\
\hline $\mathrm{Am} / \mathrm{Ck} / 28-52$ & $\begin{array}{l}\text { silty clay, dark greyish brown 10YR 4/2- wet, brown 10YR 4/3- dry, moist, weakly cemented, } \\
\text { sub- angular blocky structure, very fine to medium moderate (grade), friable, moderately } \\
\text { plastic, moderately hard, moderately sticky, slightly effervescence, moderately calcareous, } \\
\text { few roots }\end{array}$ \\
\hline $\mathrm{Ck} 1 / 52-86$ & $\begin{array}{l}\text { silty clay, yellowish brown 10YR 5/4- wet, yellowish brown 10YR 5/8-dry, moist, weakly } \\
\text { cemented, sub- angular blocky structure, fine to coarse, moderate (grade),friable, moderately } \\
\text { plastic, moderately hard, strongly effervescent, moderately sticky, strongly calcareous, } \\
\text { spherical carbonate concretions, few roots; }\end{array}$ \\
\hline Ck2/86 - 120 & $\begin{array}{l}\text { silty clay, brownish yellow 10YR 6/6-dry, brownish yellow 10YR 6/8-wet, dry, structure less, } \\
\text { fine to coarse single grain, friable, slightly plastic, slightly hard, very strongly calcareous, } \\
\text { slightly sticky, strongly effervescent, spherical carbonate concretions, few roots }\end{array}$ \\
\hline Soil type & \multicolumn{1}{c}{ Haplic chernozem } \\
\hline
\end{tabular}

Table 2. The physical and chemical data of the soil

\begin{tabular}{|c|c|c|c|c|}
\hline Horizons & Amp & $\mathrm{Am} / \mathrm{Ck}$ & Ck1 & Ck2 \\
\hline Depth $(\mathrm{cm})$ & $0-28$ & $28-52$ & $52-86$ & $86-120$ \\
\hline \multicolumn{5}{|l|}{ Texture } \\
\hline Coarse sand $(2.0-0.2 \mathrm{~mm}) \%$ & 0.73 & 0.72 & 0.63 & 0.34 \\
\hline Fine sand $(0.2-0.02 \mathrm{~mm})$ & 14.90 & 19.98 & 17.92 & 16.27 \\
\hline Dust I $(0.02-0.05 \mathrm{~mm}) \%$ & 9.15 & 8.78 & 8.94 & 9.87 \\
\hline Dust II $(0.05-0.002 \mathrm{~mm}) \%$ & 19.15 & 14.56 & 20.64 & 24.14 \\
\hline Clay $(<0.002 \mathrm{~mm}) \%$ & 56.07 & 55.96 & 51.87 & 49.38 \\
\hline Texture & SIC & SIC & SIC & SIC \\
\hline \multicolumn{5}{|l|}{ Physical analysis } \\
\hline Coarse fragments (skeleton) $\%$ & - & - & - & - \\
\hline Bulk density $\mathrm{g} / \mathrm{cm}^{3}$ & 1.13 & - & 1.41 & - \\
\hline Total Porosity \% & 58 & - & 48 & - \\
\hline \multicolumn{5}{|l|}{ Chemical analysis } \\
\hline $\mathrm{pH}$ & 7.87 & 7.91 & 8.19 & 8.20 \\
\hline Interpreting & Slightly alkaline & Slightly alkaline & Slightly alkaline & Slightly alkaline \\
\hline
\end{tabular}




\begin{tabular}{|l|c|c|c|c|}
\hline Carbonates \% & 0.7 & 8.4 & 24.0 & 32.6 \\
\hline Humus \% & 3.49 & 2.89 & - & - \\
\hline $\mathrm{N}$ total \% & 0.207 & 0.148 & - & - \\
\hline $\mathrm{P}$ mobile $(\mathrm{ppm})$ & 65 & 20 & - & - \\
\hline $\mathrm{K}$ mobile $(\mathrm{ppm})$ & 400 & 332 & - & - \\
\hline
\end{tabular}

\section{RESULTS AND DISCUSSION}

The multiannual average for 63 years was $9.2^{\circ} \mathrm{C}$ and the multiannual amount for 63 years was $531.4 \mathrm{~mm}$. The thermic regime during April - August 2020 (average $16.7^{\circ} \mathrm{C}$ ) was closer to the normal multiannual average for this period $\left(16.4^{\circ} \mathrm{C}\right)$ with $+0.3^{\circ} \mathrm{C}$ deviation, but the precipitation $(373.6 \mathrm{~mm})$ exceeded the value of multiannual average $(332.9 \mathrm{~mm})$ with + $40.7 \mathrm{~mm}$ (Figure 1 and 2). Specific to this year (during April - August) was the uneven distribution of precipitation, there were dry periods of time, with prolonged pedological droughts followed by torrential rains.

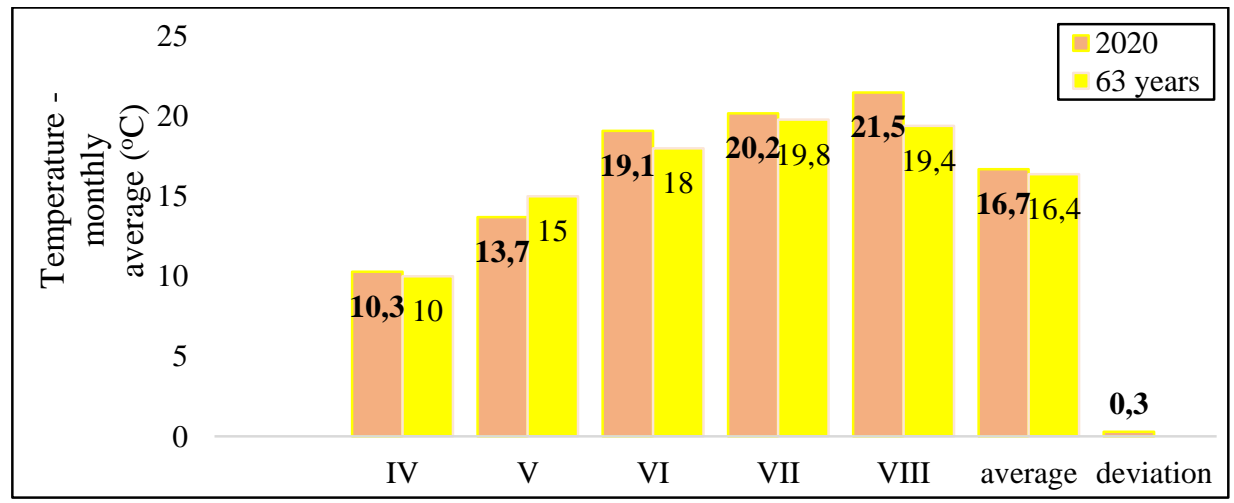

Figure 1. Thermic regime during the April - August 2020 at ARDS Turda

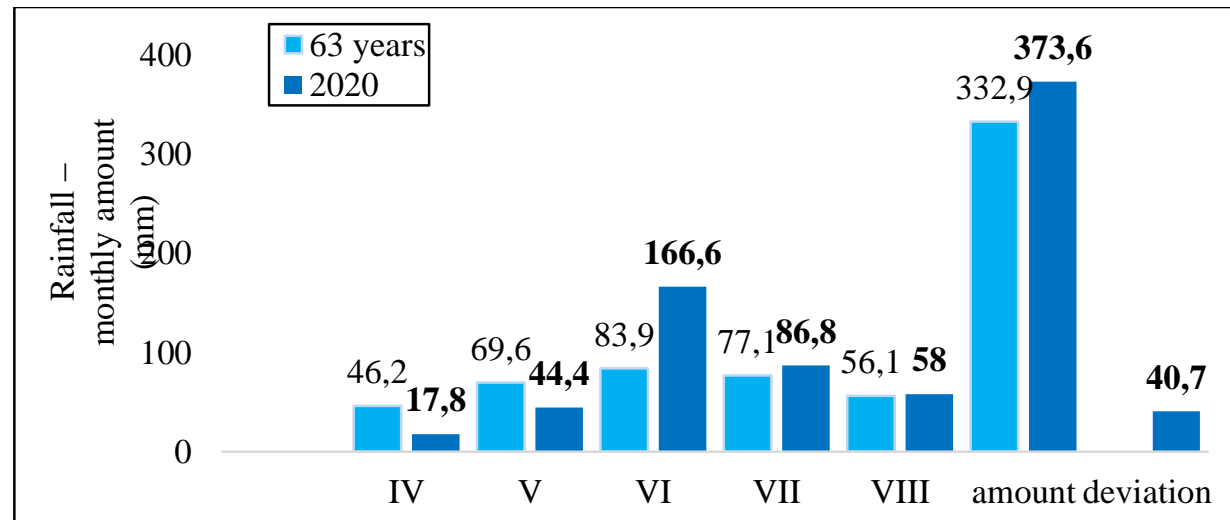

Figure 2. Rainfall regime during the April - August 2020 at ARDS Turda

The specific resistance of the soil to penetration $(\mathrm{Rp})$ is one of the main indicators that mechanically characterizes the state of soil settlement (pressing of soil particles) and was measured in this case, to determine comparatively the influence of tillage systems on soil mechanics resistance.

From the data presented in Figure 3, it is observed that in the first $30 \mathrm{~cm}$ depth the $\mathrm{Rp}$ values are lower in the systems CS and MT, this fact is mainly due to the mobilization of the soil on this depth (plowed and scarified). In MD where the soil mobilization was performed at a depth of $12 \mathrm{~cm}$, the $\mathrm{Rp}(\mathrm{kPa})$ values are lower in the first $10 \mathrm{~cm}$ depth. Although the values 
of the NT system $(1687 \mathrm{kPa})$ are higher compared to the other systems. Above the depth of 20 $\mathrm{cm}$, the resistance values increase in all tillage systems, being below 2700 in CS and MT and over $3000 \mathrm{kPa}$ in MD and NT.

At a depth of $30-40 \mathrm{~cm}$ it can be seen that the values are reduced in NT $(2865 \mathrm{kPa})$, close to CS (2977 kPa). In MT and MD the soil resistance also has high values (3106 - 3447 $\mathrm{kPa}$ ). Above the depth of $40 \mathrm{~cm}$ the resistance being below $4000 \mathrm{kPa}$ in CS (3978), MT (3731) and values over 4000 in MD (4486) and NT (4045).

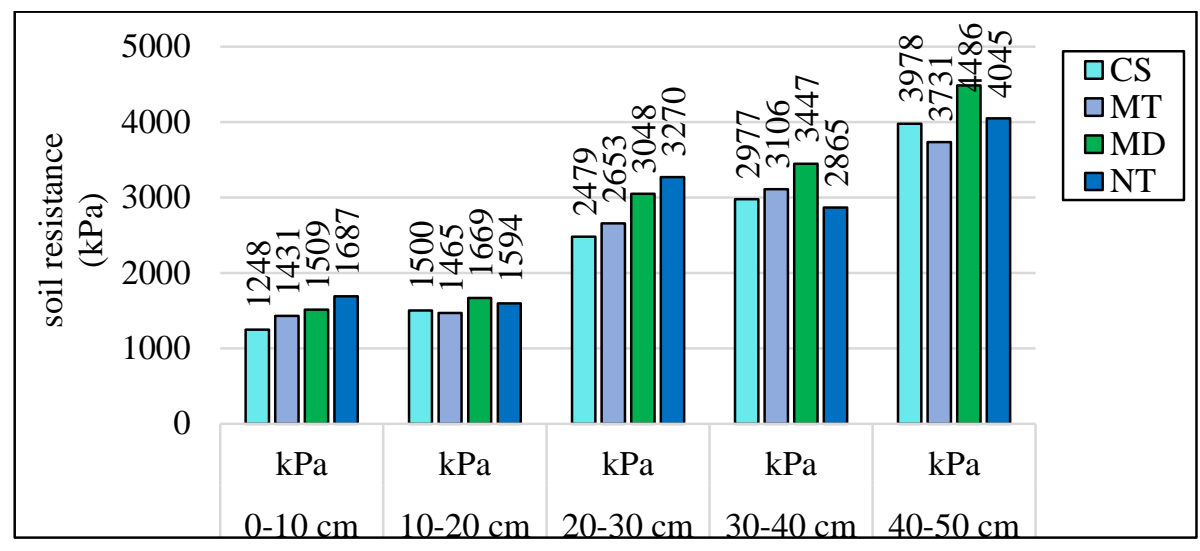

Figure 3. The specific resistance of the soil to penetration, 2020

Soil moisture determined in the four tillage systems: CS, MT, MD and NT, on the 10 $20 \mathrm{~cm}$ and 40-50 cm depth, in the two repetitions. Regarding the soil moisture determined for each tillage system, at 10-20 cm depth (Table 3) it can be seen that under the conditions of 2020 the momentary water reserve was higher in the MD tillage system $(50.5 \mathrm{~mm})$ compared to the control (CS $49.5 \mathrm{~mm}$ ) with a difference of $1.0 \mathrm{~mm}$ but without statistical assurance. From the data presented in Table 4 it can be seen that the momentary water reserve determined on the depth of 10-20 cm in April - June with values between 53.75 - $55.13 \mathrm{~mm}$ has a very significant positive influence on the development of soybean but from the end of July and until end of August the water supply was greatly reduced due to lack of rainfall, which had a negative impact on soy and thus on yield.

Table 3. The influence of the tillage system on the momentary water reserve at $10-20 \mathrm{~cm}$ depth

\begin{tabular}{|c|c|c|c|}
\hline A-tillage system & Moisture $(\mathbf{m m})$ & $\mathbf{\%}$ & Difference \\
\hline $\mathrm{a}_{1}-\mathrm{CS}$ & 49.5 & 100 & $0.00^{\mathrm{Mt}}$ \\
\hline $\mathrm{a}_{2}-\mathrm{MT}$ & 49.9 & 100.8 & $0.42^{-}$ \\
\hline $\mathrm{a}_{3}-\mathrm{MD}$ & 50.5 & 102.0 & $1.00^{-}$ \\
\hline $\mathrm{a}_{4}-\mathrm{NT}$ & 48.4 & 97.8 & $-1.08^{-}$ \\
\hline \multicolumn{2}{|c|}{ LSD $(\mathrm{p} 5 \%)=4 ; \mathrm{LSD}(\mathrm{p} \mathrm{1 \% )}=7.3 ; \mathrm{LSD}(\mathrm{p} \mathrm{0.1 \% )=16.2.}$} \\
\hline
\end{tabular}

Table 4. Momentary water reserve in the soil at 10-20 cm depth during April - August 2020

\begin{tabular}{|c|c|c|c|}
\hline P-period (month) & Moisture (mm) & $\%$ & Difference \\
\hline $\mathrm{p}_{0}-$ mean & 49.58 & 100 & $0.00^{\mathrm{Mt} .}$ \\
\hline $\mathrm{p}_{1}-$ April & 55.13 & 111.2 & $5.54^{* * *}$ \\
\hline $\mathrm{p}_{2}-$ May & 54.50 & 109.9 & $4.92^{* * *}$ \\
\hline $\mathrm{p}_{3}$ - June & 53.75 & 108.4 & $4.17^{* * * *}$ \\
\hline $\mathrm{p}_{4}$ - July & 50.13 & 101.1 & $0.54^{-}$ \\
\hline $\mathrm{p}_{5}-$ August & 44.13 & 89.0 & $-5.46^{000}$ \\
\hline \multicolumn{4}{|c|}{$\operatorname{LSD}(\mathrm{p} 5 \%)=1.97 ; \operatorname{LSD}(\mathrm{p} 1 \%)=2.67 ; \mathrm{LSD}(\mathrm{p} 0.1 \%)=3.62$} \\
\hline
\end{tabular}


From the values of the momentary water reserve presented in Table 5, in the four tillage systems, the beneficial effect of the conservative systems MT $(173.92 \mathrm{~mm})$ and NT (177.08 $\mathrm{mm}$ ) can be observed from the values registered on the depth $40-50 \mathrm{~cm}$. The differences from the classic system $(171.67 \mathrm{~mm})$ were between $2.25-5.42 \mathrm{~mm}$ and had a statistical assurance (significant and distinctly significantly positive) of water retention in the soil at a depth of 40$50 \mathrm{~cm}$. It seems that in these systems even if the water accumulates harder it is better kept and the water loss is slower.

Determinations at the same depth during April - August (Table 6) indicated that the water reserve in the first 4 months was above $180 \mathrm{~mm}$ (very significant positive influence) after which there was a water deficit in August below $150 \mathrm{~mm}$ (very significant negative influence).

Table 5. The influence of the tillage system on the momentary water reserve at $40-50 \mathrm{~cm}$ depth

\begin{tabular}{|c|c|c|c|}
\hline A-tillage system & Moisture (mm) & \% & Difference \\
\hline $\mathrm{a}_{1}-\mathrm{CS}$ & 171.67 & 100 & $0.00^{\mathrm{Mt}}$ \\
\hline $\mathrm{a}_{2}-\mathrm{MT}$ & 173.92 & 101.3 & $2.25^{*}$ \\
\hline $\mathrm{a}_{3}-\mathrm{MD}$ & 170.33 & 99.2 & $-1.33^{-}$ \\
\hline $\mathrm{a}_{4}-\mathrm{NT}$ & 177.08 & 103.2 & $5.42^{* *}$ \\
\hline \multicolumn{2}{|l|}{ LSD $(\mathrm{p} \mathrm{5 \%})=2.01 ; \mathrm{LSD}(\mathrm{p} \mathrm{1 \%})=3.68 ; \mathrm{LSD}(\mathrm{p} \mathrm{0.1 \% )=8.17.}$} \\
\hline
\end{tabular}

Table 6. Momentary water reserve in the soil at 40-50 cm depth during April-August 2020

\begin{tabular}{|c|c|c|c|}
\hline P-period (month) & Moisture (mm) & $\%$ & Difference \\
\hline $\mathrm{p}_{0}-$ mean & 173.25 & 100 & $0.00^{\mathrm{Mt} .}$ \\
\hline $\mathrm{p}_{1}-$ April & 189.00 & 109.1 & $15.75^{* * *}$ \\
\hline $\mathrm{p}_{2}-\mathrm{May}$ & 188.38 & 108.7 & $15.13^{* * *}$ \\
\hline $\mathrm{p}_{3}$-June & 184.38 & 106.4 & $11.13^{* * *}$ \\
\hline $\mathrm{p}_{4}$ - July & 181.00 & 104.5 & $7.75^{* * *}$ \\
\hline $\mathrm{p}_{5}-$ August & 156.25 & 90.2 & $-17.00^{000}$ \\
\hline
\end{tabular}

Expenditures on materials (seed, fertilizers, pesticides) were approximately equal in all four tillage systems (around 1200 lei/ha), the efficiency of the systems being determined only in terms of fuel consumption (Table 7).

Table 7. Fuel consumption for technological works /1.0 hectare

\begin{tabular}{|c|c|c|c|}
\hline \multirow{2}{*}{ Tillage system } & \multicolumn{2}{|c|}{ Mechanical works } & \multirow{2}{*}{$\begin{array}{c}\text { Yield } \\
(\mathrm{kg} / \mathrm{ha})\end{array}$} \\
\cline { 2 - 4 } & Diesel consumption (liter/ha) & Diesel price (lei/ha) & 2795 \\
\hline CS (clasic with plow) & 66.5 & 277 & 2688 \\
\hline MT (minimum tillage with chisel) & 61.5 & 256 & 2409 \\
\hline MD (minium tillage with disk) & 45.5 & 189 & 2281 \\
\hline NT (no tillage - direct sown) & 34.8 & 145 & 25 \\
\hline
\end{tabular}

The difference between the fuel consumption achieved between CS and MT is insignificant only of 5.0 liter/ha at a price of 20.5 lei/ha. Compared to CS significant reductions are made in the MD system (- 21 liter/ha at a price of 86.1 lei) and in the NT (- 31.7 liter/ha at a price of 129.97 lei). From the research carried out (Stănilă et al., 2013) it results at soybean culture the fuel consumption for the each tillage variant: 60.2 liter/ha in chisel variant, 65.3 liter/ha in heavy disk variant, 46.4 liter/ha in ridge-tillage comparative with 70.1 liter/ha consumption registered in the plow variant.

The CS and MC system proved to be superior to MD and NT systems, the yield data confirm this fact. Similar result reached in experiment with soybeans on the heavy soil (the 
content of clay more than 53\%) of East Slovak (Kováč et al., 2014) in the years 2010 - 2012, they studied the effect of three tillage systems (minimum tillage, classical and no-tillage) and they report that the higher yields was achieved at classic and minimum tillage variant and not indicating a significantly difference of the yield between these variants but the soybean yield in the no tillage variant was significantly lower.

\section{CONCLUSIONS}

Due to tillage up to 30 depth, penetration resistance values are lower in CS and MT system (below $2700 \mathrm{kPa}$ ) and above $3000 \mathrm{kPa}$ in MD system (soil mobilization on $12 \mathrm{~cm}$ ) and NT (without processing).

Although the NT (no-tillage) and MD (minimum tillage with disk) systems slightly restrict the exploration of deeper soil structures by soybean plant roots, the reduction in fuel consumption indicates the expansion of these systems.

In MD and NT system the water accumulates harder but is better preserved and water loss is slower. The soils worked deeper (CS, MT) offer a better infiltration of water from rainfall but its loss is faster.

As an alternative to the classical system, soybeans can be cultivated in a MT, the yield difference compared to the CS is insignificant (just $107 \mathrm{~kg} / \mathrm{ha}$ ).

In the pedological conditions in the experimental area, soybeans are less suitable for cultivation in the minimum-disk and directly sown system, the low production data confirm this fact.

\section{ACKNOWLEDGEMENTS}

This paper was supported by a grant of the Romanian Ministry of Research and Innovation, CCCDI- UEFISCDI, project number PN-III-P1-1.2-PCCDI-2017-0301, contract no. $28 \mathrm{PCCDI} / 2018$

\section{REFERENCES}

CHET AN, F. (2019). The influence of the tillage system and the crop rotation on the soil availability in the main nutrients and the yields obtained in Turda area. Scientific papers. Series A. Agronomy, 62,1, 19-23.

CHEŢAN, F., CHEŢAN, C. (2019). The long-term effect of the soil tillage systems, fertilization and rotation soybean-winter wheat-maize on certain soil attributes and yields specific to different pedoclimatic conditions, in Turda Area. ProEnvironment, 12, 64-70.

CHEŢAN, F., MUREŞANU, F., MALSCHI, D., CHEȚAN, C., SUCIU, L. (2019). The influence of the different tillage systems on the abundance of pests in the soy culture, in the conditions of the Transylvania Plain. Romanian Journal for Plant Protection, 13, 23-30.

CHEŢAN, F., CHEŢAN, C. (2020). The identifying some technological measures to efficiency soybean cultivation in the Transylvanian Plain. In volume symposium Agricultural and Mechanical engineering, Jubilee Edition, Bucharest, 30 October 2020, 86-92.

CHEŢAN, F., SUCIU, L., CHEŢAN, C., TĂRĂU, A., CRIŞAN, I., MUREŞANU, F. (2020). Study on soil protection by applying complex methods of sustainable management of the soybean crop agrosystem Romanian Journal for Plant Protection, 8, 60-67.

SUBRAMANIAN, S., SMITH, D.L.A. (2013). A proteomics approach to study soybean and its symbiont Bradyrhizobium japonicum - a review. INTECH Open Access Publisher 3-30.

CVIJANOVIC, D., CVIJANOVIĆ, G. (1988). Display and assessment of the dynamic development of production and consumption of soybean in the world. Economics of agricultural, 35, 11-12, 687-697. 
KOVÁČ L., JAKUBOVÁ J., ŠARIKOVÁ D. (2014). Effect of Tillage System and Soil Conditioner Application on Soybean (Glycine Max (L.) Merrill) and Its Crop Management Economic Indicators. Agriculture, 60, 2, 60-69.

STEVANOVIC, P., POPOVIC, V., FILIPOVIĆ, V., TERZIĆ, D., RAJIČIĆ, V., SIMIĆ, D., TATIĆ, M., TABAKOVIĆ, M. (2017). Influence of fertilization at the nitrogen content and mass of the nodule of soybean (Glycine max (L.) Merr). Journal of Institute of PKB Agroekonomik, Belgrade, 23, 1-2, 119128.

POPOVIĆ, V., ŽIVANOVIĆ, L.J., KOLARIĆ, L. J., IKANOVIĆ, J., SIMIĆ, D., TATIĆ, M., STEVANOVIC, P. (2018). Effect of nitrogen fertilization on the yield components of soybean (Glycine max (L.) Merr). Journal of Institute of PKB Agroekonomik, Belgrade, 24, 1-2, 101-110.

SERRANO J., PEÇA J., MARQUES DA SILVA J., PINHEIRO A., CARVALHO M. (2007). Tractor energy requirements in disc harrow systems. Biosystems Engineering, 98, 3, 286-296.

MARCHENKO, V.V., KOTKO, I.G., OPALKO, V.G. (2009). Technologies and technical means of sowing with minimal and zero processing. Agrarian engineering and equipment, 1, 6, 03, 20-28.

PISANTE, M, STAGNARI, F. (2011). Agricoltura blu - la via Italiana dell'agricoltura conservative. Manuale abbreviato, Associazione Italiana per la Gestione Agronomica e Conservativa del Suolo, Ancona, Italy, 1-51.

MARIN, D. I., RUSU, T., MIHALACHE, M., ILIE, L., NISTOR, E., BOLOHAN, C. (2015). Influence of soil tillage system upon the yield and energy balance of corn and wheat crops. Agrolife Scientific Journal, 4, 2, 43-47.

SABO, M., JUG, D., JUG, I. (2007). Effect of Reduced Tillage on Quality Traits of Soybean. Acta Agronomica, 55, 1, 83-88.

STĂNILĂ, S., DROCAŞ, I., MOLNAR, A., RANTA, O. (2013). Studies regarding comparative fuel consumption at classical and conservative tillage. ProEnvironment, 6, 199-202.

TOPA, D., AILINCĂI, C., RĂUŞ, L., ANTONESCU, M., JITĂREANU, G. (2012). Effect of tillage on soybean crop yield and physical properties on a cambic chernozem. International conference RAGUSA SHWA 2012, Safety Health and Welfare in Agriculture and in Agro-food Systems, September 3-6, 2012, Ragusa-Italy, 597-603.

ULRICH, S., HOFMANN, B., TISCHER, S., CHRISTEN, O. (2006). Influence of tillage on soil quality in a long term trial in Germany. Soil Management for Sustainability, 110-116.

WOZNIAK, A., MAKARSKI, B., STEPNIOWSKA, A. (2014). Effect of tillage system and previous crop on grain yield, grain quality and weed infestation of durum wheat. Romanian Agricultural Research, 31, 1-9.

SZAJDAK, L.W., RUSU, T. (2016). Free sulfuric amino acids and rhodanese in soils under rye cropping and crop rotation. In: Bioactive Compounds in Agricultural Soils. Ed. Szajdak L.W. Springer International Publishing Switzerland, 91-122. DOI: 10.1007/978-3-319-43107-9_4.

MESP (1987). Pedologic Studies Elaboration Metodology. Pedologic and Agrochemical Ins. Bucharest, $1-3$.

Meteorological Station Turda Office for Pedological and Agrochemical Studies Cluj-Napoca (2017).

POLIFACT (2015). ANOVA and Duncan's test PC program for variant analyses made for completely randomized poly-factorial experiences.

SRTS (2012). Romanian System of Soil Taxonomy. Ed. Estfalia, Bucharest. 